\title{
ÜVEGGÖMBHÉJ ERŐSÍTÉSÛ́ ALUMÍNIUM MÁTRIXÚ SZINTAKTIKUS FÉMHAB KVÁZI-STATIKUS NYOMÓVIZSGÁLATA
}

\section{QUASI-STATIC COMPRESSION TESTS OF GLASS HOLLOW SPHERES FILLED ALUMINIUM MATRIX SYNTACTIC FOAM}

\author{
Keresztes Zoltán ${ }^{1}$, Ladányi-Pára Gergely ${ }^{2}$, Katona Bálint ${ }^{3}$ \\ ${ }^{I}$ Budapesti Müszaki és Gazdaságtudományi Egyetem, Gépészmérnöki Kar, \\ Anyagtudomány és Technológia Tanszék, 1111 Magyarország, Budapest, Bertalan \\ Lajos utca 7. MT épület, Tel.:00361-463-1114, krzoli10@gmail.com \\ ${ }^{2}$ Óbudai Egyetem, Bánki Donát Gépész és Biztonságtechnikai Mérnöki Kar, 1081 \\ Magyarország, Budapest, Népszínház utca 8. Tel: 00361-666-5300, \\ gyergyely@gmail.com \\ ${ }^{3}$ Budapesti Müszaki és Gazdaságtudományi Egyetem, Gépészmérnöki Kar, \\ Anyagtudomány és Technológia Tanszék, 1111 Magyarország, Budapest, Bertalan \\ Lajos utca 7. MT épület, Tel.:00361-463-1114,katona@eik.bme.hu
}

\begin{abstract}
The human race draws its ideas since the beginning from the nature. The situation is the same, when we talk about metallic foams. These materials have two bigger classes: the open, and the closed celled foams. As the second one if the cells nearly have the same form, the same size and the same relative position to each other, they are called syntactic foams. We studied the basic physical and mechanical properties of these materials like density, space filling factor, different microscopic features, hardness and answers for pressure tests. Our main goal was to recognize the basics of the glass hollow spheres filled aluminium matrix syntactic foam and the reaction for the high temperature pressure test compared to the lower (room) temperature results, furthermore planning a new industrial utilization.
\end{abstract}

Keywords: metallic foam, density, hardness, compression test, high temperature.

\section{Összefoglalás}

Az ember a kezdetek óta meríti ötleteit az öt körülölelő természetből. Épp így van ez a fémhabok esetében is. Ezek az anyagok két nagyobb csoportba sorolhatóak: nyílt és zárt cellás habok. A második esetben, ha a cellák hasonló alakúak, méretüek és egymáshoz viszonyított elhelyezkedésük is azonos, akkor szintaktikus fémhabokról beszélünk. Ezen anyagok olyan alap fizikai és mechanikai tulajdonságaikat vizsgáltuk, mint a sürüség, térkitöltési tényező, különböző mikroszkópos képek, keménység, nyomóvizsgálatokra adott válaszok. A fö célunk az üveggömbhéj erősítésủ alumínium mátrixú szintaktikus fémhabok alapjainak megismerése és az emelt hőmérsékletre adott válasza összevetve a szobahőmérsékletű eredményekkel, továbbá egy új ipari felhasználás tervezése.

Kulcsszavak: fémhab, sürüség, keménység, nyomóvizsgálat, emelt hőmérséklet 


\section{Bevezetés}

A természet és a technológia közötti szoros kapcsolat megkérdőjelezhetetlen. Az ember létezésétől kezdve alapozza találmányait a körülötte lévő élő - és élettelen szerkezetekre. A fémhabok esetében a vázszerkezet nagyban hasonlít a fák, korallok, csontok belső lyukacsos (cellás) felépítéséhez. A fémhaboknál, ha ezek a cellák hasonló méretüek, zártak és egymáshoz viszonyítva hasonló elhelyezkedésüek, akkor szintaktikus fémhabokról beszélünk [1].

A paraméterek beállításához segítségül vettünk több kutató kísérleteit. Rohatgi és társai azt vizsgálták, hogy a térkitöltési tényező hogyan befolyásolja az energia elnyelését [2]. Wu és csoportja a sürüség növelésének hatását vizsgálták nyomószilárdságra [3].

A kapott eredmények alapján egy új ipari felhasználást is terveztünk, ami forradalmasíthatja finommegmunkálásokat leppelés, stb.

\section{Anyag és módszer}

$\mathrm{Az}$ általunk vizsgált fémhab mátrix anyaga AlSi12 öntészeti alumínium ötvözet, erősítőanyaga pedig $\sim 60 \mu \mathrm{m}$ átmérőjü nikkel bevonatú üveggömbhéjak voltak [4]. A vizsgált anyagot inertgáz nyomásos infiltrációval készítettük [5].

Elsődleges célunk a vizsgált anyag föbb fizikai tulajdonságainak megismerése (sürüség, keménység), valamint a nyomó terhelésre adott válaszának megfigyelése szoba-, illetve emelt hőmérsékleten.

\subsection{Sürüség}

Elsőként meghatároztuk az általunk vizsgált szintaktikus fémhab sürüségét a kiöntött tömb térfogatából, illetve tömegéböl. A tömeget precíziós mérleg segítségével mértük, a térfogatot pedig 3D modellezés segítségével határoztuk meg.
Így a vizsgálat anyag sürüségére $1,58 \mathrm{~g} / \mathrm{cm}^{3}$-es adódott, ami majdnem fele az alapfém sürüségénél $\left(2,6 \mathrm{~g} / \mathrm{cm}^{3}\right)$.

\subsection{Keménység}

Ezután a vizsgált anyag keménységét határoztuk meg. Mivel az anyag nem homogén, Brinell keménységmérést alkalmaztunk, amely kiváló inhomogén anyagok átlagos keménységének meghatározására [6].

A kimunkált munkadarabon 9 helyen végeztünk keménységmérést HBS 8,5/25,5/10. Az így kapott keménység értéke 44,8 HBS, ami alul marad az alapfém 60 HBS keménységével szemben.

\subsection{Nyomóvizsgálat}

A fémhabok jellemző igénybevétele a nyomó terhelés, így fontos annak vizsgálata.

A vizsgálathoz három különböző karcsúságú $(\mathrm{h} / \mathrm{d}=1 ; \mathrm{h} / \mathrm{d}=1,5 ; \mathrm{h} / \mathrm{d}=2 ;) 10 \mathrm{~mm}$ átméröjü hengereket munkáltunk ki. A próbatesteket egy MTS 810-es típusú hidraulikus anyagvizsgáló gépen terheltük 5 $\mathrm{mm} /$ min-es nyomási sebesség mellett szoba hömérsékleten $\left(20^{\circ} \mathrm{C}\right)$, illetve $100^{\circ} \mathrm{C}$-on.

\subsubsection{Nyomóvizsgálat $20^{\circ} \mathrm{C}$-on}

$\mathrm{Az}$ 1. ábra egy $20^{\circ} \mathrm{C}$-on zömített $\mathrm{h} / \mathrm{d}=1$ karcsúságú minta mérnöki feszültségmérnöki alakváltozás görbéjét mutatja. Megfigyelhetö, hogy a kezdeti maximum érték után (nyomószilárdság) jelentős csökkenés következik be az erö értékében, ami a minta törése miatt jelentkezik. Ezt követően a minta darabjai tömörödnek. Ezen a hosszú platós szakaszon a minta nagy mennyiségü energiát képes elnyelni, melynek értéke arányos a görbe alatti területtel. A 2. ábra a törési után pillanatban lévő állapotot mutatja.

A különbözö karcsúságú minták esetében a nyomószilárdság értéke közel azonos volt, melynek számszerü értéke $272,1 \pm 1,2 \mathrm{MPa}$-ra adódott. 


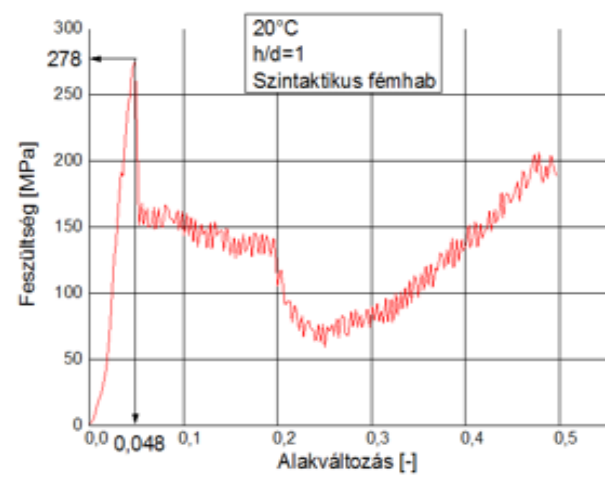

1. ábra. $20^{\circ} \mathrm{C}$-on történö nyomóvizsgálat feszültség-alakváltozás görbéje

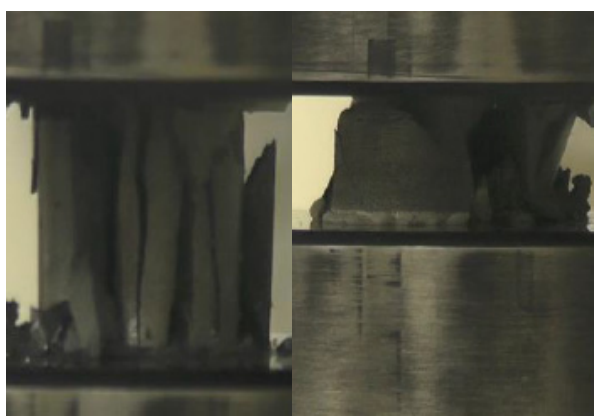

2. ábra. A próbatest $20^{\circ} \mathrm{C}$-on történö nyomóvizsgálat során tapasztalt törése: a törés pillanatában (bal), 50\%-os alakváltozásnál (jobb)

\subsubsection{Nyomóvizsgálat $100^{\circ} \mathrm{C}$-on}

A 3. ábra egy $100^{\circ} \mathrm{C}$-on zömített $\mathrm{h} / \mathrm{d}=1$ karcsúságú minta mérnöki feszültségmérnöki alakváltozás görbéjét mutatja. Megfigyelhetö, hogy a kezdeti maximum érték után (nyomószilárdság) szintén jelentős csökkenés következik be az erő értékében, hasonlóan a $20^{\circ} \mathrm{C}$-os méréseknél tapasztalthoz.

A különböző karcsúságú minták esetében a nyomószilárdság értéke közel azonos volt, melynek számszerü értéke $250,0 \pm 5 \mathrm{MPa}$-ra adódott.

Megfigyelhetö, hogy az emelt hőmérsékletü mérések esetében kisebb érték adódott az átlagos nyomószilárdság értékére. Ez a mátrix anyag emelt hőmérsékleten való viselkedésének tudható be, amely így kihat az egész kompozitra.

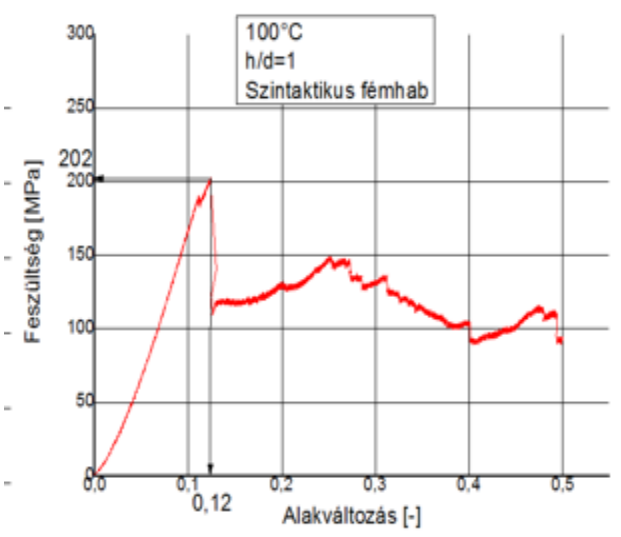

3. ábra. $100^{\circ} \mathrm{C}$-on történö nyomóvizsgálat feszültség-alakváltozás görbéje

\subsubsection{Belső szerkezet vizsgálata}

A roncsolódott munkadarabok belső szerkezetét szintén vizsgáltuk. A mintákból metszetet készítettünk, ezeket gyantába öntöttük és políroztuk. A kapott felületekről mikroszkópos képeket készítettünk, aminek elemzésével egy átfogóbb képet kaptunk a minták belső szerkezetében a nyomás hatására lejátszódó folyamatokról.

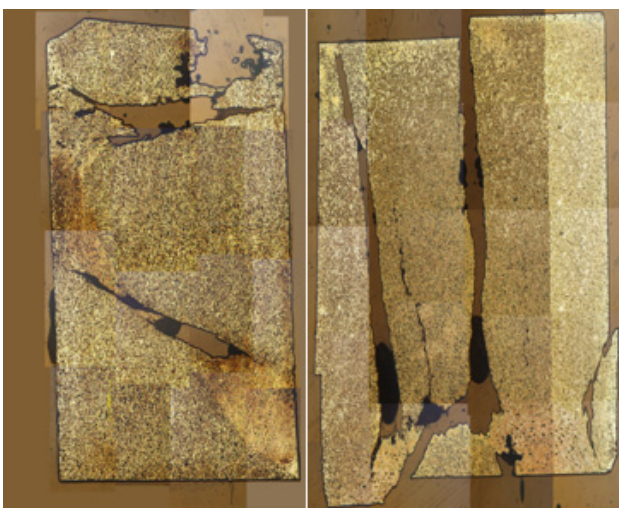

4. ábra. Összeillesztett mikroszkópos képek a zömitett próbatestek keresztmetszetéröl 
Megfigyelhetők a teljes próbatesten átmenő repedések, amelyek a nyomószilárdság elérésekor keletkeztek, majd ezt követően terjedtek. A repedések átmetszik az üveggömbhéjakat, amelyek töretfelületei így élesek lesznek. Megfigyelhetőek mátrix anyaggal feltöltött üveggömbhéjak is. Ezek a hibák az infiltrálás során képződtek.

Nagyobb nagyítású képeket készítettünk a repedésektől távoli (bal) és ahhoz közeli (jobb) területekről.

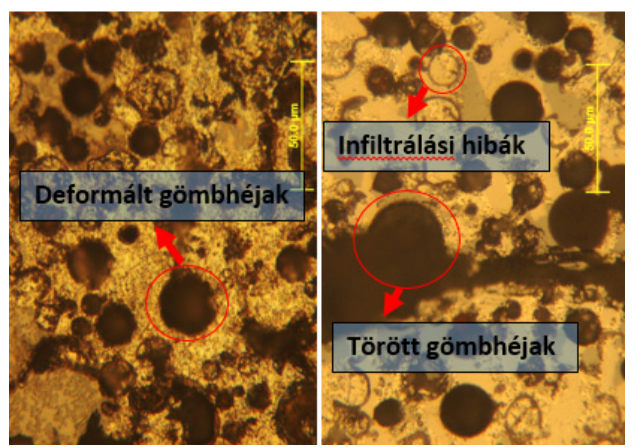

5. ábra. Zömités hatása a repedésektöl távol (bal) és közel (jobb)

\section{Következtetések}

A vizsgálatok során megállapítottuk, hogy az általunk vizsgált szintaktikus fémhab sürüsége $\sim 60 \%$-a az alapfémnek, értéke $1,58 \mathrm{~g} / \mathrm{cm} 3$.

A 9 mért keménységi érték átlaga $(44,8$ HBS) azt mutatja, hogy a vizsgált fémhabunk keménysége $25 \%$-a a mátrixfém keménységének. Ezt érdemes figyelembe venni a felhasználásánál is.

A nyomóvizsgálatok alapján megállapíthatjuk, hogy a vizsgált anyag a nyomószilárdság elérése után széttörik, utána pedig tömörödik. $\mathrm{Az}$ emelt hőmérséklet az erősítőanyagra nincs, de a mátrix anyagra jelentősen hatással van, ami a vizsgált kompozit tulajdonságaira is kihat.

A mikroszkópos felvételeken jól látható, hogy az üveggömbhéjak ridegen törtek. Az így kialakuló éles töretfelületek feltételezéseink szerint jók lehetnek anyagleválasztásra, a leválasztott anyag pedig az üveggömbhéj belső üreges felületében tárolódik.

Ezeket figyelembe véve a vizsgált anyag bizonyos feltételek mellett köszörü anyagként alkalmazható lenne.

\section{Szakirodalmi hivatkozások}

[1] Dr. Orbulov Imre Norbert: Szintaktikus fémhabok, Phd értekezés, Budapest, 2009

[2] Rohatgi PK, Kim JK, Gupta N, Alaraj S, Daoud A: Compressive characteristics of A356/fly ash cenosphere composits synthesized by pressure infiltration technique, Volume 37, Issue 3, Március 2006

[3] Wu Gh, Dou ZY, Sun DL, Jiang LT, Ding BS, He BF: Compression behaviors of cenosphere-pure aluminium syntactic foams, Volume 56, Issue 3, Február 2007

[4] Dr. Ing Catrin Kammer: Aluminium foam, TALAT Lecture 1410, EAA, 1999

[5] Orbulov I. N., Berecz T., Májlinger K., Szabó J.: Infiltration characteristic and compressive behaviour of metal matrix syntactic foams, Material science forum 729 , 2013

[6] Ge Leyi, Zhao Wei, Zhou Jing, Huang Songling: Mechanics analysis and simulation of material Brinell hardness measurement, Volume 44, Issue 10, December 2011, 21292137 